\title{
LEFT VENTRICULAR ASSIST DEVICE WITH CONCOMINANT TRICUSPID VALVE REPAIR: IMPACT ON RIGHT VENTRICULAR REVERSE REMODELLING AND SURVIVAL
}

\author{
Povilas Jakuška ${ }^{1}$, Rasa Veisaitè ${ }^{2}$, Rokas Ereminas ${ }^{1}$, Vilija Grumuldytè ${ }^{3}$, Ramūnas Bolys ${ }^{1}$, \\ Eglè Ereminien $\dot{e}^{2}$ \\ ${ }^{1}$ Department of Cardiac Surgery, Lithuanian University of Health Sciences, Kaunas, Lithuania, \\ ${ }^{2}$ Department of Cardiology, Lithuanian University of Health Sciences, Kaunas, Lithuania, \\ ${ }^{3}$ Lithuanian University of Health Sciences, Kaunas, Lithuania
}

Key words: left ventricular assist device, tricuspid valve repair, right ventricular remodeling.

\begin{abstract}
Summary
Background. In the end stage heart failure (HF) patients with moderate to severe tricuspid regurgitation (TR), the surgical decision for tricuspid valve (TV) repair during left ventricular assist device (LVAD) implantation surgery is not clear.

Methods. We included 31 patient with end-stage heart failure and moderate to severe TVR ( $\geq$ II degree) to our retrospective study analysis. 19 patients received TV annuloplasty during LVAD implantation (TVR+ group), whereas 12 patients didn't (TVR- group). Demographic, clinical and echocardiographic parameters were assessed in both groups preoperatively and 1 month after surgery. Overall 12 months survival was analysed with Kaplan - Meier method and compared between groups.

Results. Inhospital or 30 days mortality rate in TVR+ and TVR- groups was $21.1 \%$ and $8.3 \%$, respectively $(\mathrm{p}=0.624)$. The overall survival rates up to 12 months did not differ between groups (75\% vs $57.89 \%$, $\mathrm{p}=0.452$ ). TV regurgitation grade was reduced significantly after LVAD implantation with $(\mathrm{p}=0.001)$ and without TV repair $(\mathrm{p}=0.008)$. Dimensions of RV and right atrium decreased in TVR+ group $(\mathrm{p}<0.001)$. The size of RV did not change significantly in TVRgroup postoperatively, however, the diameter of right atrium reduced significantly in this group $(p=0.01)$. Systolic and mean pulmonary artery pressures decreased significantly in both groups of patients. The indices of RV longitudinal function were reduced
\end{abstract}

preoperatively and did not change after LVAD implantation with and without TV repair.

Conclusions. Pulmonary artery pressures decreased in all patients after LVAD implantation, while the diameter of RV reduced significantly in patients after concomitant TV repair. Early postoperative mortality and 1 year survival rates did not differ between end stage heart failure patients after LVAD implantation with or without TV annuloplasty.

\section{Introduction}

Owing to donor heart shortage, left-ventricular assist devices (LVAD) are increasingly used as a bridge to heart transplantation in patients with end stage heart failure. In some patients, end-stage left ventricular dysfunction is associated with hemodynamically significant functional tricuspid valve (TV) regurgitation leading to further dilatation of the right heart chambers, progression of right ventricular dysfunction [1]. LVAD implantation usually results in unloading of left ventricle and a consecutive reduction in mitral and tricuspidal regurgitation grade. Some studies result that, in case of LVAD implantation, the concomitant TV repair (TVR) has no benefit regarding clinical outcome [2]. Other authors conclude that TV reconstruction reduces the incidence of postoperative right heart failure (RHF) and does not increase the operative risk $[3,4]$. However, the surgical decision for TV repair together with LVAD implantation in end staged heart failure patients with moderate to severe functional TV regurgitation remains not clear.

The aim of our study was to analyze 1-year survival and echocardiographic parameters of right ventricle (RV) size and function in patients after LVAD implantation with or without TV annuloplasty. 


\section{Materials and methods}

The study group consisted of retrospectively included 31 patient with end-stage heart failure and moderate to severe TR treated from 2009 through 2017 in the Hospital of Lithuanian University of Health Sciences Kaunas clinics. 19 patients received TV annuloplasty during LVAD implantation (TVR+ group), whereas 12 patients did not (TVR-group). Demographic, clinical and echocardiographic parameters were assessed in both groups preoperatively and 1 month after surgery. Conventional echocardiographic measurements were obtained according to recommendations of American Association of Echocardiography $[5,6]$.

All LVAD implantations were performed via median sternotomy and with cardiopulmonary bypass (CPB). Patients with concomitant TVR underwent bicaval cannulation for total CPB. TV annuloplasty was performed using suture annuloplasty technique at the level of the anteroposterior and posteroseptal commissures. Regarding the magnitude of the TV annular compression was made by using modified De Vega method.

Statistical analyses were performed using the SPSS 21.0 software. Data are presented as mean $\pm \mathrm{SD}$ for continuous variables, and as frequencies and percentages (\%) for ca-

Table 1. Baseline characteristics of the study groups AH - arterial hypertension, LVAD - left ventricular assist device.

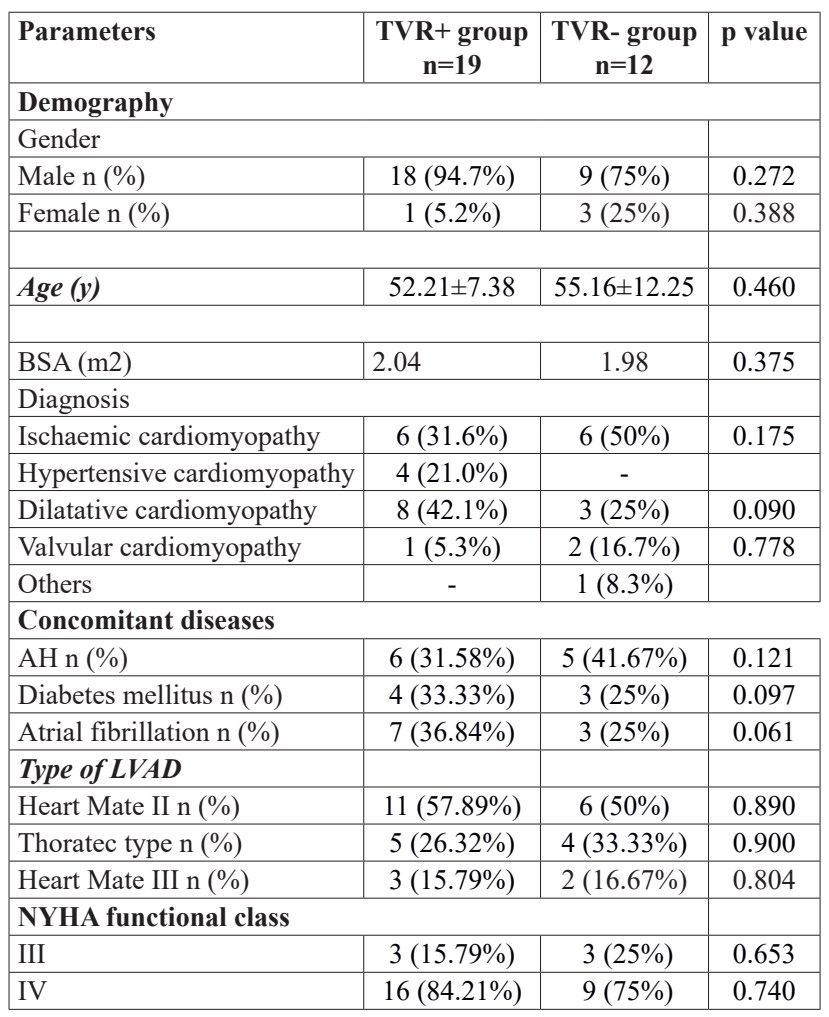

tegorical variables. Differences of characteristics between groups were calculated using „Wilcoxon rank-sum“ test. The value of $\mathrm{p}<0.05$ was considered as statistically significant. Overall 1 year survival was analysed with Kaplan - Meier method and compared between groups.

Consent for the study was obtained from local bioetics committee (No. BEC-MF331).

\section{Results}

Baseline characteristics and perioperative parameters. Baseline characteristics of the study groups are given in Table 1. The age, gender, body surface area, NYHA functional class, medicamental heart failure treatment did not differ between groups. The prevalence of dilated and ischaemic cardiomyopathy, concomitant diseases (arterial hypertension, diabetes mellitus, atrial fibrillation) was similar in both groups of patients.

Three types of LVAD were implanted: $54.8 \%$ of the patients received Heart Mate II, 16.1\% - Heart Mate III and $29.1 \%$ of the patients - Thoratec paracorporal type LV assist device. Types of implanted LVAD did not differ between the groups. Compared with the TVR-group, operation time and CPB time were not significantly longer in the TVR+ group $(266.00 \pm 56.46$ vs $253.53 \pm 49.46 \mathrm{~min}, \mathrm{p}=0.57$ and $145.55 \pm 25.70$ vs $137.6 \pm 48.0 \mathrm{~min}, \mathrm{p}=0.63$ respectively).

Primary end points. During the study period 11 patients died after LVAD implantation: 3 patients $(25.0 \%)$ in the TVR- group and 8 patients $(42.11 \%)$ in TVR+ group. Causes of death in the TVR- group were sepsis $(n=1)$, cerebrovascular adverse events $(n=1)$, multiple organ failure $(n=1)$. In the $\mathrm{TVR}+$ group the causes of death were multiple organ failure $(\mathrm{n}=4)$, sepsis $(\mathrm{n}=2)$, cerebrovascular adverse events $(\mathrm{n}=2) .6$ patients $(31.58 \%)$ had been transplanted in TVR+ group and 4 patients $(33.33 \%)$ - in TVR- group $(\mathrm{p}=0.919)$. The overall mean duration of left ventricular assist device support before transplantation did not differ between the groups - 175.67 \pm 40.10 days for the patients in TVR+ group and $297.67 \pm$ 76.60 days for the patients in TVR- group $(\mathrm{p}=0.196)$.

Early postoperative mortality rate in TVR + and TVRgroup was $21.1 \%$ and $8.3 \%$ respectively $(\mathrm{p}=0.624)$. The overall survival rates up to 12 months did not differ between groups ( $75 \%$ vs $57.89 \% \mathrm{p}=0.452$ ). (Figure 1 ).

Analysis of echocardiographic data. LV end diastolic diameter reduced in all patients after LVAD implantation. TV regurgitation grade decreased significantly in both groups after LVAD implantation. RV size and the diameter of RA diameter decreased significantly after LVAD and TV repair $(p<0.001)$. The size of RV did not change in the group without TV repair $(\mathrm{p}=0.58)$.

Systolic and mean pulmonary artery pressures decreased 
significantly in both groups. The indices of RV longitudinal function (TAPSE, S') were reduced preoperatively and did not change after LVAD implantation with and without TV repair. Changes of echocardiographic data between groups are presented in Table 2.

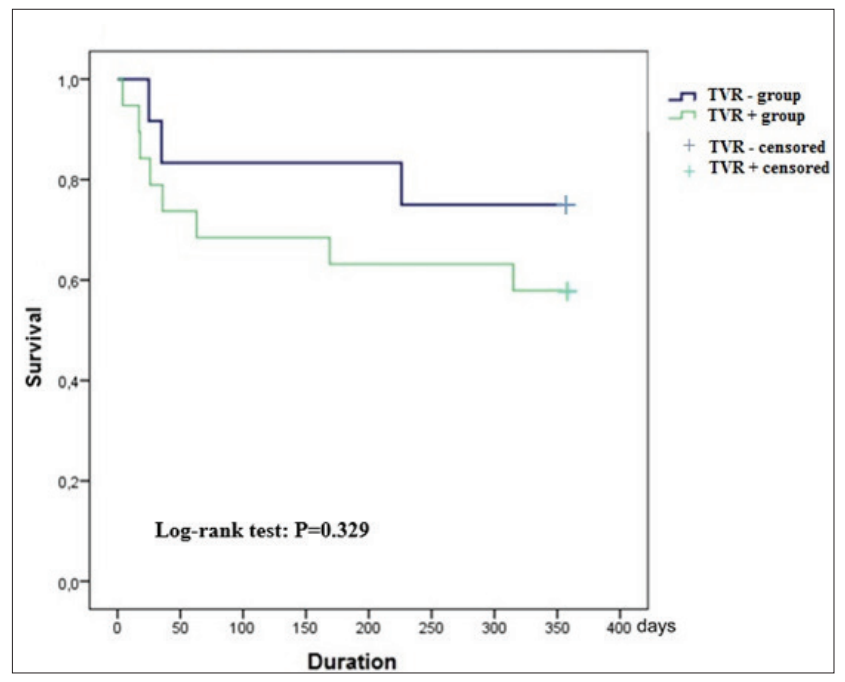

Figure 1. One-year overall survival according to the study group. The follow-up time of each patient began at the day of LVAD implantation.

\section{Discussion}

Patients with advanced heart failure and coexisting valvular heart disease who undergo LVAD implantation constitute a growing population with challenges in clinical and surgical management. This group of patients develop symptoms of biventricular failure with dilatation of both ventricles. Dilatation of the RV leads to tricuspid annular dilation, apical leaflet displacement and reduced coaptation length, progression of functional tricuspidal regurgitation. Several studies revealed that almost half of patients with end staged heart failure have moderate to severe TR that further contributes to RV volume overload and progression of RV dysfunction $[3,7]$. Piacentino V., as well as Kormos RL. et al. showed that worsening RV failure after LVAD implantation is associated with reduced survival $[3,8]$, that's why TV pathology remains a major concern at the time of surgery.

Several studies demonstrated that LVAD therapy reduces LV end diastolic pressure and pulmonary pressures. This decreases RV afterload, can normalize right heart hemodynamics, improve RV function and reduce the grade of TR [16]. Krishan. et al. demonstrated similar hemodynamics and mean central venous pressure early postoperatively (13.5 vs $14 \mathrm{mmHg} ; \mathrm{p}=0.10)$ and mean pulmonary artery pressure $(25$ vs $25.6 \mathrm{mmHg}$; $\mathrm{p}=0.76$ ) after isolated LVAD implantation [4]. Piacentino. et al. found that at late follow up (mean 156 272 days), moderate to severe TR decreased significantly (32\% versus $49 \%$ preoperatively) [4]. Morgan. et al confirmed this data: qualitative RV

Table 2. Changes of echocardiographic data after LVAD implantation with or without TV repair $L V E D D$ - left ventricular end diastolic diameter, RVEDD - right ventricular end diastolic diameter, RA - right atrium, PAP - pulmonary arterial pressure, TAPSE - tricuspidal annular plane systolic excursion, TR - tricuspidal regurgitation.

\begin{tabular}{|l|c|c|c|c|c|c|}
\hline & \multicolumn{3}{|c|}{$\begin{array}{c}\text { TVR+ group } \\
\text { (average } \pm \text { standart deviation) }\end{array}$} & \multicolumn{3}{c|}{$\begin{array}{c}\text { TVR- group } \\
\text { (average } \pm \text { standart deviation) }\end{array}$} \\
\hline $\begin{array}{l}\text { Variables } \\
\text { LVAD im- } \\
\text { plantation }\end{array}$ & $\begin{array}{c}\text { Postopera- } \\
\text { tive }\end{array}$ & $\begin{array}{c}\mathbf{p} \\
\text { value }\end{array}$ & $\begin{array}{c}\text { Before } \\
\text { LVAD im- } \\
\text { plantation }\end{array}$ & $\begin{array}{c}\text { Postopera- } \\
\text { tive }\end{array}$ & $\begin{array}{c}\mathbf{p} \\
\text { value }\end{array}$ \\
\hline LVEDD (mm) & $68.32 \pm 6.47$ & $58.47 \pm 9.47$ & $\mathbf{p}=\mathbf{0 . 0 0 3}$ & $69,83 \pm 6.75$ & $56.33 \pm 8.96$ & $\mathbf{p}=\mathbf{0 . 0 0 8}$ \\
\hline RVEDD (mm) & $48.74 \pm 7.26$ & $40.29 \pm 7.29$ & $\mathbf{p}<\mathbf{0 . 0 0 1}$ & $40.25 \pm 5.21$ & $36.56 \pm 5.433$ & $\mathrm{p}=0.580$ \\
\hline $\begin{array}{l}\text { RAP (mm) } \\
\text { (mmHg) }\end{array}$ & $58.68 \pm 10.78$ & $51.21 \pm 12.22$ & $\mathbf{p}<\mathbf{0 . 0 0 1}$ & $50.83 \pm 7.52$ & $43.33 \pm 2.87$ & $\mathbf{p}=\mathbf{0 . 0 1 3}$ \\
\hline $\begin{array}{l}\text { PAP mean } \\
\text { (mmHg) }\end{array}$ & $41.84 \pm 6.79$ & $34.50 \pm 5.29$ & $\mathbf{p}=\mathbf{0 . 0 0 6}$ & $42.08 \pm 4.70$ & $43.38 \pm 4,63$ & $\mathbf{p}=\mathbf{0 . 0 1 7}$ \\
\hline TAPSE (mm) & $11.74 \pm 3.30$ & $11.13 \pm 5.29$ & $\mathbf{p}=0.180$ & $11.75 \pm 3.25$ & $10.33 \pm 1.5$ & $\mathrm{p}=0.431$ \\
\hline S' (cm/s) & $6.58 \pm 2.17$ & $5.67 \pm 2.09$ & $\mathrm{p}=0.060$ & $6.25 \pm 2.38$ & $5.22 \pm 1.39$ & $\mathrm{p}=0.431$ \\
\hline TVR grade & $3.11 \pm 0.74$ & $0,89 \pm 1.81$ & $\mathbf{p}=\mathbf{0 . 0 0 1}$ & $2.33 \pm 0.65$ & $1.08 \pm 0.73$ & $\mathbf{p}=\mathbf{0 . 0 0 8}$ \\
\hline
\end{tabular}
function on echocardiography improved from $57.1 \%$ moderately or severely reduced pre-operatively to $38.1 \%$ at 1 month (p $=0.008)$ and severity of TR decreased from $11.4 \%$ moderate or severe pre-operatively to $4.8 \%$ at 1 month $(\mathrm{p}<0.001)$. These improvements were maintained at 6 months post-LVAD implantation [9]. In contrast, Holman. et al. found that TR even worsened and that RV dilatation persisted after LVAD implantation [10]. Westaby S. added that even when an LVAD reduces pulmonary artery pressure, tricuspid insufficiency tends to be progressive in the long term, eventually reducing transpulmonary flow and pump output and that this is problematic for destina- 
tion therapy patients who survive for several years and whose pump output falls when tricuspid regurgitation worsens [11].

Our study revealed that systolic and mean pulmonary pressures decreased significantly in all patients after LVAD implantation. The grade of TR, as well, as the right atrium reduced significantly in both groups.

Our study results are consisted with the data from Maltais. et al study, that reported evidence of reverse RV remodelling [12]. This study also found the improvement of RV function after LVAD with concomitant TV surgery, though data are lacking to inform us, whether these early changes translate into differences in long-term outcomes. Our study results did not show the improvement of the longitudinal RV free wall function after LVAD implantation with or without TV annuloplasty.

Our data demonstrated the safety of tricuspid annuloplasty in the setting of LVAD implantation - TV repair did not take more than $20 \mathrm{~min}(266.00 \pm 56.46$ vs $253.53 \pm 49.46$ min, $\mathrm{p}=0.57)$ and did not add time substantially to duration of cardiopulmonary bypass ( $145.55 \pm 25.70$ vs $137.60 \pm 48.00$ $\min , \mathrm{p}=0.635$ ). Early postoperative mortality was not statistically different between groups $(\mathrm{p}=0.624)$. These results are in agreement with Krishnan K. et al study findings. They found that TV repair did not increase the operation time significantly and demonstrated similar hospital mortality in both groups (TVR $+18.9 \%$ versus TVR- $14.2 \% ; p=0.7$ ) [4]. Pal JD. et al also confirmed these findings - concomitant valve procedures did not increase operative mortality after HeartMate II implantation, the overall 30-days mortality was $11.8 \%$ for LVAD implantation and concomitant valve procedures [13]. Some studies present different results - Saeed D. et al. showed that TVR+ group had a longer cardiopulmonary bypass time $(\mathrm{p}<0.01)$ and higher percent of postoperative complications were found in this group of patients, though there was no significant difference in short- or longterm mortality between the groups [2].

There are very limited data provided in any of the studies on long-term outcomes. The data from the HeartMate II trials reported no difference in 1-year (77\% vs. $75 \%$ ) survival in patients treated with LVAD and TV repair vs LVAD alone [14]. Song HK. et al presented the INTERMACS Registry results of 989 patients, who underwent LVAD implantation with moderate and severe TR. It was concluded that moderate to severe TR at the time of LVAD implantation was associated with poorer survival over entire follow up period $(\mathrm{p}=0.009)$. But interestingly, concomitant TV repair did not improve 48 months survival $(\mathrm{p}=0.83$ ). A potential explanation for this finding was that late recurrent TR developed in 21 to $27 \%$ of the TVR+ group patients [15]. Our study results are in agreement with these data presenting similar overall survival rates up to 12 months between groups $(75 \%$ vs $57.89 \%, \mathrm{p}=0.452$ ).

\section{Conclusions}

Pulmonary artery pressures decreased in all patients after LVAD implantation, while the diameter of RV reduced significantly in patients after concomitant TV repair. Early postoperative mortality and 1 year survival rates did not differ between end stage heart failure patients after LVAD implantation with or without TV annuloplasty.

\section{Limitations}

Our data are limited by the relatively small sample size, retrospective design, and non-randomized allocation.

\section{List of abbreviations}

AH - arterial hypertension; BSA - body surface area; CPB cardiopulmonary bypass; $\mathbf{H F}$ - heart failure; $\mathbf{L V}$ - left ventricle; LVAD - left-ventricular assist device; LVEDD - left ventricular end diastolic diameter; NYHA - New York Heart Association; PAP pulmonary artery pressure; RA - right atrium; RHF - right heart failure; RV - right ventricle; RVEDD - right ventricular end diastolic diameter; TAPSE - tricuspidal annular plane systolic excursion; TV - tricuspid valve; TR - tricuspidal valve regurgitation.

\section{References}

1. Oezpeker C, Zittermann A, Paluszkiewicz L. et al. Tricuspid valve repair in patients with left-ventricular assist device implants and tricuspid valve regurgitation: propensity score-adjusted analysis of clinical outcome. Interact Cardiovasc Thorac Surg 2015; 21 (6):741-747.

https://doi.org/10.1093/icvts/ivv260

2. Saeed D, Kidambi T, Shalli S, et al. Tricuspid valve repair with left ventricular assist device implantation: is it warranted? J Heart Lung Transplant 2011; 30:530-535.

https://doi.org/10.1016/j.healun.2010.12.002

3. Piacentino V III, Williams ML, Depp T. et al. Impact of tricuspid valve regurgitation in patients treated with implantable left ventricular assist devices. Ann Thorac Surg 2011;91: 1342-6. https://doi.org/10.1016/j.athoracsur.2011.01.053

4. Krishan K, Nair A, Pinney S, Adams DH, Anyanwu AC. Liberal use of tricuspid-valve annuloplasty during left-ventricular assist device implantation. Eur J Cardiothorac Surg 2012; 41: 213-217.

https://doi.org/10.1016/j.ejcts.2011.05.047

5. Lang RM, Badano LP, Mor-Avi V. et al. Recommendations for cardiac chamber quantification by echocardiography in adults: an update from the American Society of Echocardiography and the European Association of Cardiovascular Imaging. J Am Soc Echocardiogr 2015;28(1):1-39. 
https://doi.org/10.1016/j.echo.2014.10.003

6. Stainback RF., Estep JD., Agler DA. et al. Echocardiography in the management of patients with left ventricular assist devices: recommendations from the American Society of echocardiography. J Am Soc. Echocardiogr 2015; 28: 853-909.

https://doi.org/10.1016/j.echo.2015.05.008

7. Wang TS., Hernandez AF., Felker GM. et al. Valvular heart disease in patients supported with left ventricular assist devices. Circ Heart Fail 2014; 7:215-222. https://doi.org/10.1161/CIRCHEARTFAILURE.113.000473

8. Kormos RL, Teuteberg JJ, Pagani FD. et al. HeartMate II Clinical Investigators. Right ventricular failure in patients with the HeartMate II continuous- ow left ventricular as- sist device: incidence, risk factors, and effect on outcomes. J Thorac 2010; 139:1316-1324.

https://doi.org/10.1016/j.jtcvs.2009.11.020

9. Morgan JA., Paone G., Nemeh HW. et al. Impact of continuousflow left ventricular assist device support on right ventricular function. J Heart Lung Transplant 2013; 32; 398-403. https://doi.org/10.1016/j.healun.2012.12.018

10. Holman WL, Bourge RC, Fan P, Kirklin JK. et al. Influence of longer term left ventricular assist device support on valvular regurgitation. ASAIO J. 1994;40:M454-M459 https://doi.org/10.1097/00002480-199407000-00041

11. Wetaby S. Tricuspid regurgitation in left ventricular assist device patients. Eur J Cardiothorac Surg 2012; 41:217-218. https://doi.org/10.1016/j.ejcts.2011.06.019

12. Maltais S, Topilsky Y, Tchantchaleishvili V. et al. Surgical treatment of tricuspid valve insufficiency promotes early reverse remodeling in patients with axial-flow left ventricular assist devices. J Thoracic Cardiovasc Surg 2012; 143:1370-1376. https://doi.org/10.1016/j.jtcvs.2011.07.014

13. Pal JD, Klodell CT, John R, Pagani FD, Rogers JG, Farrar DJ, Milano CA. Low operative mortality with implantation of a continuous flow left ventricular assist device and impact of concurrent cardiac procedures. Circulation 2009; 120:S215-9. https://doi.org/10.1161/CIRCULATIONAHA.108.844274

14. John R, Naka Y, Park SJ, Sai-Sudhakar C, et al. Impact of concurrent surgical valve procedures in patients receiving continuous-flow devices. J Thorac Cardiovasc Surg 2014; 147:581-589.

https://doi.org/10.1016/j.jtcvs.2013.10.024

15. Song HK, Gelow JM, Mudd J. et al. Limited utility of tricuspid valve repair at the time of left ventricular assist device implantation. Ann Thorac Surg. 2016; 101 (6); 2168-74.

https://doi.org/10.1016/j.athoracsur.2016.03.040

16. Atluri P, Fairman AS, Macarthur JW,. et al. Continuous flow left ventricular assist device implant significantly improves pulmonary hypertension, right ventricular contractility, and tricuspid valve competence. J Card Surg. 2013; 28:770-5.

https://doi.org/10.1111/jocs.12214

\section{KAIRIOJO SKILVELIO PAVADUOJANČIOS SISTEMOS IMPLANTAVIMAS IR TRIBURIO VOŽTUVO PLASTIKA: ITAKA DEŠINIOJO SKILVELIO REMODELIAVIMUISI IR IŠGYVENAMUMUI}

P.Jakuška, R.Veisaitė, R.Ereminas, V.Grumuldytė, R.Bolys, E.Ereminienè

Raktažodžiai: kairijị skilvelị pavaduojanti sistema (KSPS), triburio vožtuvo plastika, dešiniojo skilvelio funkcija.

Santrauka

Ivadas. Esant toli pažengusiam širdies nepakankamumui bei vidutinio - didelio laipsnio triburio vožtuvo nesandarumui (TVN) nèra aišku, ar implantuojant kairịji skilvelị pavaduojančią sistemą (KSPS), tikslinga chirurgiškai koreguoti TVN.

Tyrimo tikslas. Ivertinti ankstyvą ir vienerių metų išgyvenamumą bei dešiniojo skilvelio funkcijos ir kitų echokardiografinių parametrų kitimą po KSPS implantavimo priklausomai nuo to, ar buvo chirurgiškai koreguotas TVN.

Metodai. I retrospektyvinị tyrimą buvo ịtrauktas 31 pacientas, sergantis toli pažengusiu širdies nepakankamumu, kuriam buvo nustatytas vidutinis - didelis TVN ( $\geq$ II laipsnio). 19 pacientų implantuojant KSPS, buvo atlikta TV plastika (TVP+ grupė) ir 12 pacientu, kuriems operacijos metu TV plastika nebuvo atlikta (TVP- grupė). Abiejų grupių ligoniams vertinti demografiniai, klinikiniai ir echokardiografiniai parametrai prieš operaciją ir praejjus mènesiui po chirurginès intervencijos. 12 mènesių išgyvenamumas buvo lyginamas tarp tiriamųų grupių ir analizuojamas Kaplan- Meier metodu.

Rezultatai. Ankstyvas mirštamumas (stacionarinis/30 dienų po operacijos) TVP+ ir TVP-grupése atitinkamai buvo 21,1\% ir 8,3\% $(\mathrm{p}=0,624) .12$ mèn. išgyvenamumas tarp tiriamųjų grupių nesiskyrè (atitinkamai $75 \%$ ir $57,9 \%(p=0,452)$. TVN laipsnis reikšmingai sumažejo abiejų grupių ligoniams: atlikus TV plastiką $(\mathrm{p}=0,001)$, neatlikus TV plastikos $(p=0,008)$. Vidutinis ir sistolinis plaučių arterijos spaudimas pooperaciniu periodu statistiškai reikšmingai sumažèjo abiejų grupių ligoniams. Dešiniųjų širdies ertmių dydžiai statistiškai reikšmingai sumažejo TVP+ grupejje ( $<<0.001)$, TVPgrupès ligoniams sumažèjo tik dešiniojo prieširdžio dydis $(\mathrm{p}=0.01)$. Prieš operaciją abiejų grupių tiriamiesiems nustatyta sumažejusi dešiniojo skilvelio ilgosios ašies funkcija, kuri pooperaciniu laikotarpiu patikimai nekito.

Išvados. Sergantiems toli pažengusiu širdies nepakankamumu po KSPS implantavimo sumažèjo vidutinis ir sistolinis spaudimas plautinèje arterijoje, tačiau dešiniojo skilvelio dydis sumažejo pacientams, kuriems kartu buvo atlikta TV plastika. Chirurgiškai koreguotas TV nesandarumas neturejo įtakos ankstyvam pooperaciniam mirštamumui bei vienerių metų išgyvenamumui po KS pavaduojančios sistemos implantavimo.

Adresas susirašinèti: raaasaaa@gmail.com

Gauta 2018-04-11 